\title{
A review of the European offshore wind innovation system is
}

\author{
Anna J. Wieczorek ${ }^{\mathrm{a}, \mathrm{b}, *}$, Simona O. Negro ${ }^{a}$, Robert Harmsen ${ }^{\mathrm{a}}$, Gaston J. Heimeriks ${ }^{\mathrm{a}}$, \\ Lin Luo ${ }^{c}$, Marko P. Hekkert ${ }^{\mathrm{a}}$ \\ a Innovation Studies, Copernicus Institute of Sustainable Development, Faculty of Geosciences, Utrecht University, Heidelberglaan 2, 3584 CS Utrecht, \\ The Netherlands \\ ${ }^{\mathrm{b}}$ Institute for Environmental Studies, Vrije Universiteit Amsterdam, de Boelelaan 1085, 1087 HV Amsterdam, The Netherlands \\ ${ }^{\mathrm{c}}$ European Commission, DG JRC, Institute for Energy and Transport, P.O. Box 2, 1755 ZG Petten, The Netherlands
}

\section{A R T I C L E I N F O}

\section{Article history:}

Received 17 October 2012

Received in revised form

9 May 2013

Accepted 20 May 2013

Available online 21 June 2013

\section{Keywords:}

Offshore wind

Technological innovation system

Systemic problems

Systems functions

Systemic instruments

\begin{abstract}
A B S T R A C T
Offshore wind has the potential of becoming an important pillar of the future European energy system. It can contribute to policy objectives on climate change, energy security, green growth and social progress. However, the large potential of offshore wind does not automatically lead to a large share in future energy systems; neither does the emergent stage of development of the technology. Recent insights in innovation studies suggest that the success chances of technological innovations are, to a large extent, determined by how the surrounding system-the innovation system-is built up and how it functions. In this paper we assess the offshore wind innovation systems of four countries: Denmark, the UK, the Netherlands and Germany with the objective to provide recommendations for strengthening the overall European offshore wind innovation system. We use the Technological Innovation System (TIS) approach to analyse the system in 2011. Based on the analysis we identify a number of challenges that the European offshore wind sector faces. Some of them include: a serious deficiency of engineers; fragmented policies and poor alignment of national regulatory frameworks; cost of the technology and limited grid infrastructure. Since the problems hinder the entire system development we call for a systemic policy instrument that would support the innovation system around this technology and contribute to its wider diffusion in Europe.
\end{abstract}

(c) 2013 Elsevier Ltd. All rights reserved.

\section{Contents}

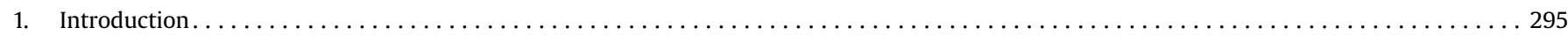

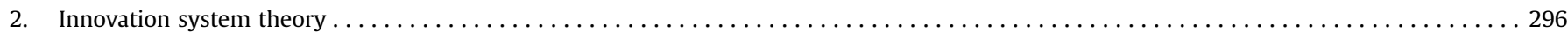

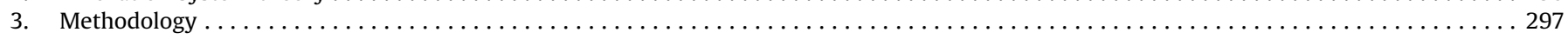

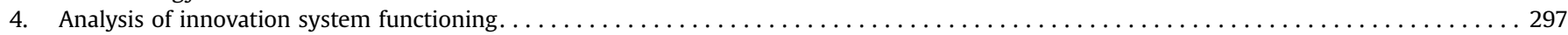

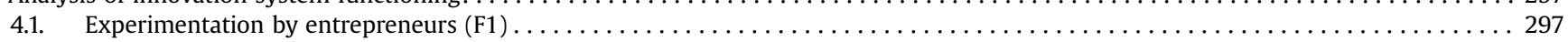

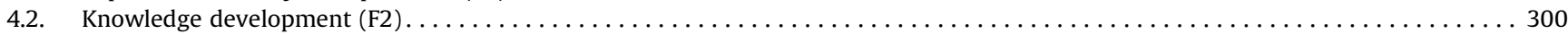

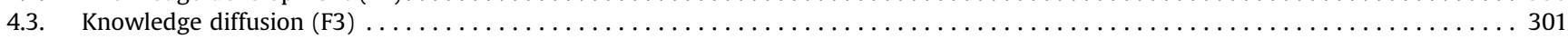

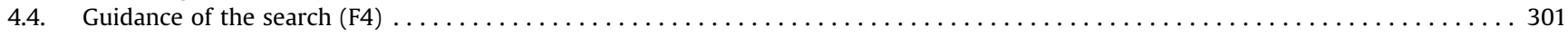

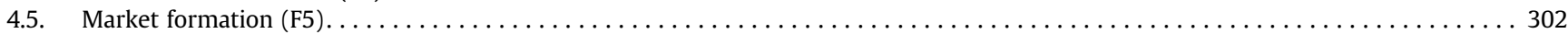

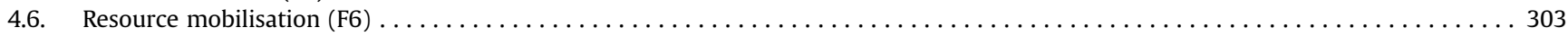

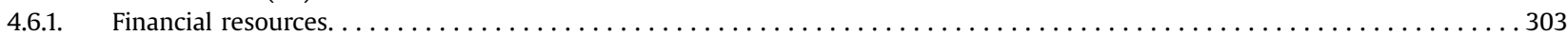

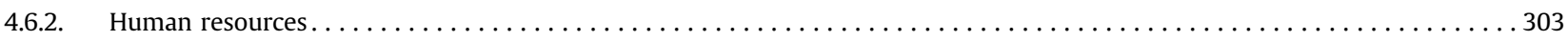

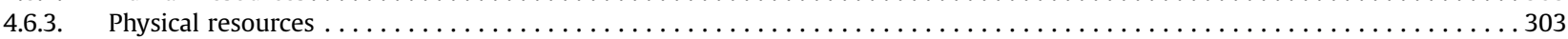

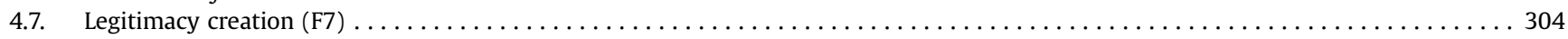

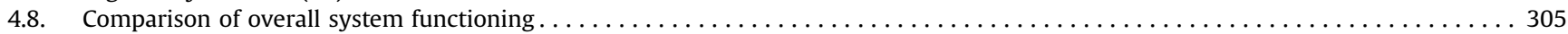

\footnotetext{
${ }^{n}$ The views expressed in this paper are purely those of the writers and may not in any circumstances be regarded as stating an official position of the European Commission.

* Corresponding author at: Innovation Studies, Copernicus Institute of Sustainable Development, Faculty of Geosciences, Utrecht University, The Netherlands.

Tel.: +3130253 1625; fax: +31302532746.
}

E-mail address: A.J.Wieczorek@uu.nl (A.J. Wieczorek). 


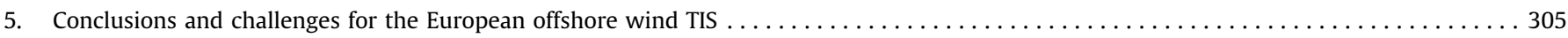

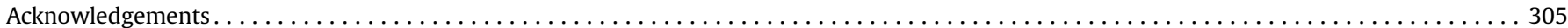

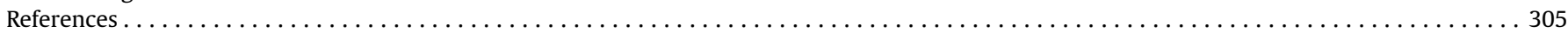

\section{Introduction}

The development and diffusion of offshore wind energy technology is important for European energy policy [1,2]. Firstly, there is a large amount of potential: the European Wind Energy Association (EWEA) expects $150 \mathrm{GW}$ of offshore wind capacity to be realised in 2030, which would supply $14 \%$ of Europe's electricity demand [3]. The technical potential of offshore wind in Europe is estimated at 5800 GW [4] and allows for even further expansion after 2030. Offshore wind has thus the possibility of becoming an important pillar of the future European energy system, contributing to policy objectives on climate change, energy security and affordable energy [5]. Secondly, the technology is in the early stages of technological development and, therefore, many business opportunities can be reaped in this emerging sector and thereby contributing to green economic growth. However, a large potential does not automatically lead to a large share in future energy systems; neither does an emergent stage of technological development automatically lead to success for companies and the related economic growth and growth in employment. Innovation and technological change are by definition very uncertain processes. The outcomes are strongly determined by processes of chance and by external events that can hardly be influenced. Nevertheless, the scientific community that studies innovation has shown that a conscious and intelligent management of innovation processes strongly increases the success chances of innovation $[6,7,9]$.

The most important insight that has dominated the field of innovation studies in the recent decades is the fact that innovation is a collective activity and takes place within the context of an innovation system. The success chances of innovations are, therefore to a large extent, determined by how the innovation system is built up (defined as structure of the innovation system) and how it functions. Many innovation systems are characterised by flaws that hamper the development and diffusion of innovations. These flaws are often labelled as system failures [6]; or system problems [7]. Intelligent innovation policy therefore evaluates how innovation systems are functioning, tries to create insight into the system problems and develops policies accordingly.

This paper assesses the offshore wind innovation system of four countries: Denmark, the UK, the Netherlands and Germany with the objective to provide recommendations for strengthening the overall European offshore wind innovation system. We chose the countries mainly because of their largest installed capacity in 2011 (the UK-1586 MW, Denmark-854 MW, the Netherlands247 MW and Germany-195 MW [3]). The second reason is the potential high contributions of these countries to European offshore wind. We use the Technological Innovation System (TIS) approach to analyse the state of the system in 2011. We also identify the weaknesses that may hinder its further development.

The paper is structured as follows: Sections 2 and 3 describe the theory and methodology applied in this paper. In Section 4 we look into the structure and functioning of the innovation systems in the UK, Denmark, the Netherlands and Germany. The paper closes with concluding remarks in Section 5 on challenges of the European offshore wind innovation system.

Table 1

Description of the seven key processes of innovation systems.

\begin{tabular}{|c|c|c|}
\hline Key process & Description & Diagnostic question \\
\hline $\begin{array}{l}\text { Experimentation } \\
\text { by } \\
\text { entrepreneurs }\end{array}$ & $\begin{array}{l}\text { Entrepreneurs are essential for a well functioning innovation system. Their role is to turn } \\
\text { the potential of new knowledge, networks, and markets into concrete actions to generate } \\
\text { — and take advantage of-new business opportunities. }\end{array}$ & $\begin{array}{l}\text { Are there sufficient } t^{\mathrm{a}} \text { and suitable types of actors } \\
\text { contributing to entrepreneurial experimentation and up- } \\
\text { scaling? } \\
\text { Are the amount and type of experiments of the actors } \\
\text { sufficient? } \\
\text { How much technological up -scaling takes place? }\end{array}$ \\
\hline $\begin{array}{l}\text { Knowledge } \\
\text { development }\end{array}$ & $\begin{array}{l}\text { Mechanisms of learning are at the heart of any innovation process, where knowledge is a } \\
\text { fundamental resource. Therefore, knowledge development is a crucial part of innovation } \\
\text { systems. }\end{array}$ & $\begin{array}{l}\text { Are there enough actors involved in knowledge } \\
\text { development and are they competent? } \\
\text { Is the knowledge sufficiently developed and aligned with } \\
\text { needs of actors in the innovation system? }\end{array}$ \\
\hline $\begin{array}{r}\text { Knowledge } \\
\text { exchange }\end{array}$ & To learn relevant knowledge needs to be exchanged between actors in the system. & $\begin{array}{l}\text { Are there sufficient networks or connection between } \\
\text { actors through which knowledge is exchanged? }\end{array}$ \\
\hline $\begin{array}{l}\text { Guidance of the } \\
\text { search }\end{array}$ & $\begin{array}{l}\text { This system function refers to those processes that lead to a clear development goal for } \\
\text { the new technology based on technological expectations, articulated user demand and } \\
\text { societal discourse. This process enables selection, which guides the distribution of } \\
\text { resources. }\end{array}$ & $\begin{array}{l}\text { Do actors and institutions provide a sufficiently clear } \\
\text { direction for the future development of the technology? }\end{array}$ \\
\hline $\begin{array}{l}\text { Market } \\
\text { formation }\end{array}$ & $\begin{array}{l}\text { This process refers to the creation of markets for the new technology. In early phases of } \\
\text { developments these can be small niche markets but later a larger market is needed to } \\
\text { facilitate cost reduction and incentives for entrepreneurs to move in. }\end{array}$ & $\begin{array}{l}\text { Is the size of the market sufficient to sustain innovation } \\
\text { and entrepreneurial experimentation? }\end{array}$ \\
\hline $\begin{array}{l}\text { Resource } \\
\text { mobilisation }\end{array}$ & $\begin{array}{l}\text { The financial, human and physical resources are necessary basic inputs for all activities in } \\
\text { the innovation system. Without these resources, other processes are hampered. }\end{array}$ & $\begin{array}{l}\text { Is the availability of financial resources sufficient? } \\
\text { Are there sufficient competent actors/well trained } \\
\text { employees? } \\
\text { Is the physical infrastructure sufficient? }\end{array}$ \\
\hline $\begin{array}{l}\text { Creation of } \\
\text { legitimacy }\end{array}$ & $\begin{array}{l}\text { Innovation is by definition uncertain. A certain level of legitimacy is required for actors to } \\
\text { commit to the new technology with investment, adoption decisions, etc. }\end{array}$ & $\begin{array}{l}\text { Do actors, formal and informal institutions sufficiently } \\
\text { contribute to legitimacy? } \\
\text { How much resistance is present towards the technology, } \\
\text { project set up or permit procedure? }\end{array}$ \\
\hline
\end{tabular}

a Since innovation does not recognize an optimum, it is impossible to judge whether there is enough of it. Our discussion on the sufficiency of innovative activity in the

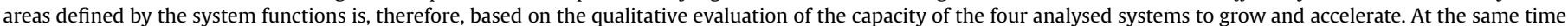
we refrain from any quantitative assessment in the context of reaching the European and national targets. 


\section{Innovation system theory}

Innovation systems highlight the interaction between actors who are needed to turn an idea into a successful process, product or service in the marketplace. A Technological Innovation System (TIS) can be defined as the set of actors and rules that influence the speed and direction of technological change in a specific technological area [8-10]. The purpose of analysing a TIS is to evaluate the development of a particular technological field in terms of the structures and processes that support or hamper it. The identified obstacles in structure and processes may then be easier addressed by a policy. By this, the TIS analysis forms an analytical building block of a systemic policy framework that helps identify and address the obstacles in a systematic and coherent way [7].

The structure of the innovation system consists of four types of components: (i) actors, (ii) institutions and (iii) interactions, operating within (iv) specific infrastructure (for a more elaborate description of the components see [7])

1. Actors involve organisations contributing to a technology such as a developer or adopter, or indirectly as a regulator, financer,

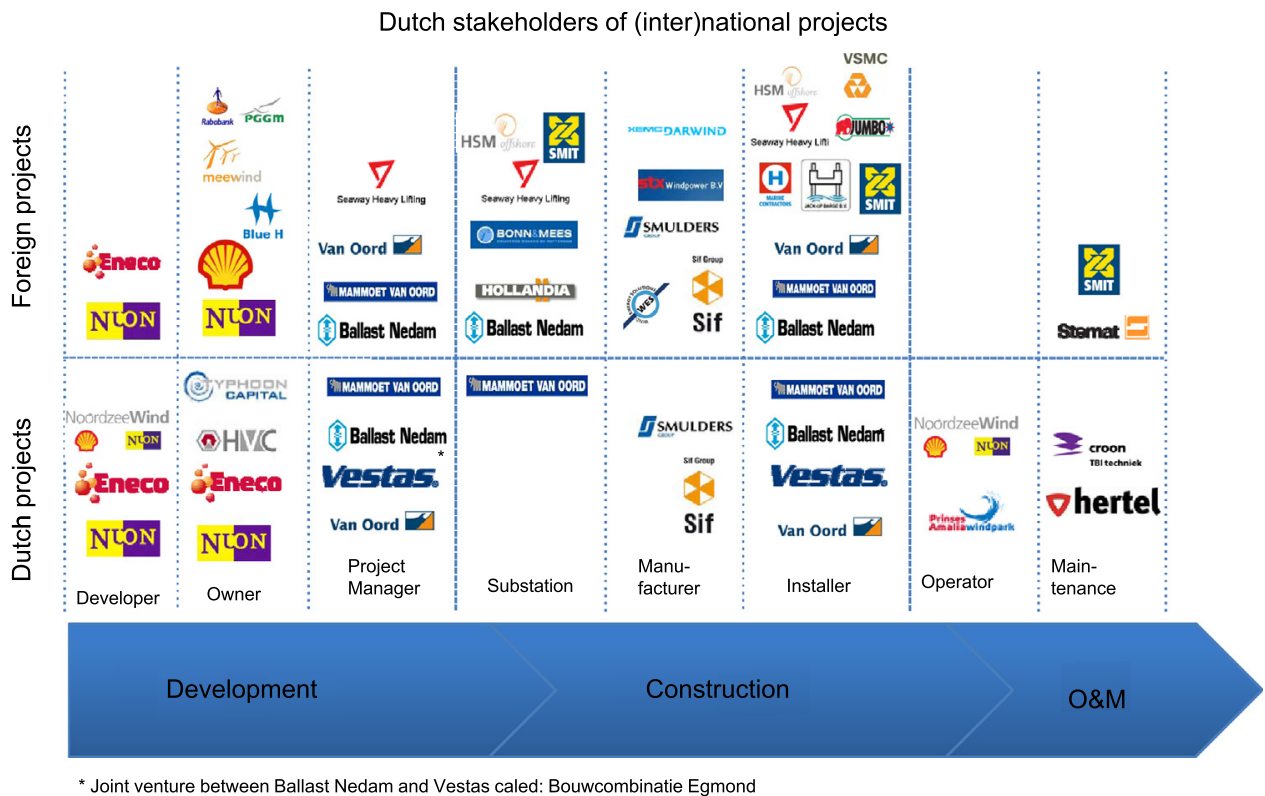

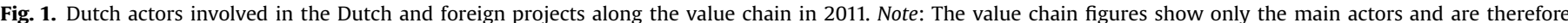

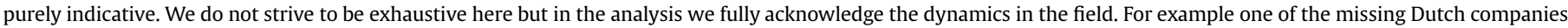

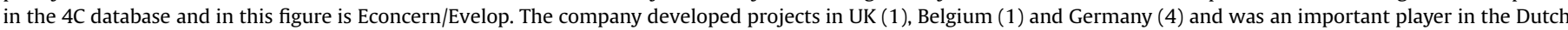
value chain but went bankrupt and does not exist anymore [18].

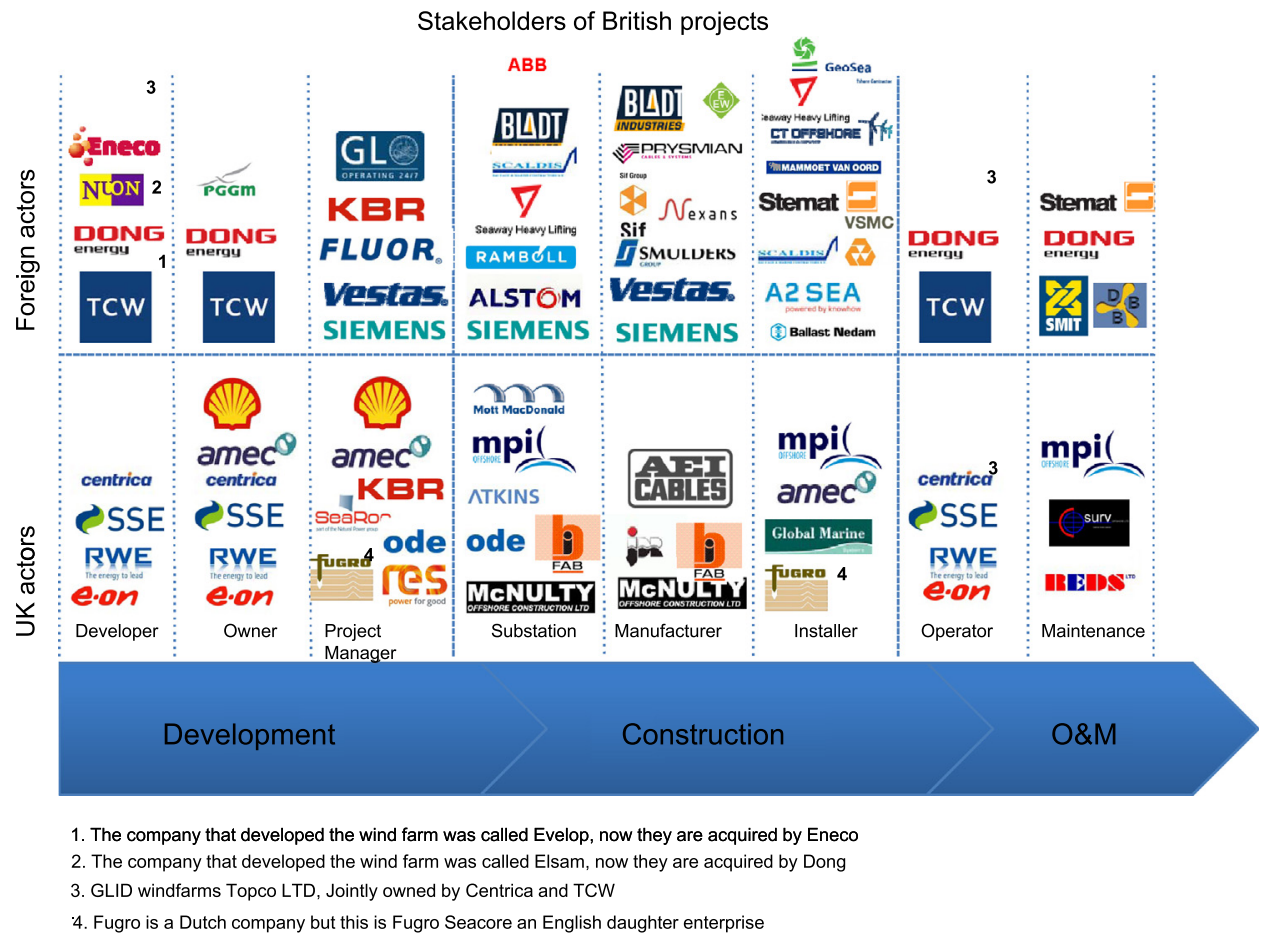

Fig. 2. The UK and international actors involved in UK offshore wind projects along the value chain. 
etc. It is the actors of a TIS that, through choices and actions, generate, diffuse and utilise technologies.

2. Institutions encompass common habits, routines and shared concepts used by humans in repetitive situations [11]. By this they are different from organisations (such as firms, universities, state bodies, etc.) [12,13]. Formal institutions encompass: policy goals, rules, laws, regulations, instructions. Informal institutions encompass: visions, customs, common habits, routines, established practices, traditions, ways of conduct, norms, and expectations. Institutions constrain and enable actors in the innovation system to undertake actions related to innovation.

3. Interactions take place between actors through networks. These interactions are essential for e.g. knowledge exchange, learning, innovation, and shared vision building.

4. Infrastructure consists of: physical, financial and knowledge infrastructure. Physical infrastructure encompasses: artefacts, instruments, machines, roads, buildings, telecom networks, bridges, harbours. Knowledge infrastructure includes: knowledge, expertise, know-how, strategic information. Financial infrastructure includes: subsidies, financial programmes, grants, venture capital, etc.

The structural analysis of systems is based on mapping its elements and evaluating their capacity to stimulate innovation. The structural elements, their presence or absence as well as their capacities are critical to the functioning of the innovation systems [7].

However, even though different innovation systems may have similar components, they may function in an entirely different way. Therefore, measuring how innovation systems are functioning is considered a big breakthrough in innovation systems research. Table 1 presents criteria that have been proposed in the literature [8] to evaluate how innovation systems are functioning. These assessment criteria are labelled in the literature as key processes of innovation systems or system functions. In order to empirically evaluate the key processes a set of diagnostic questions are used (Table 1 ).

The structure and key processes complement each other. While key processes are more evaluative in character and allow to assess the performance of an innovation system; the structure is what needs to be adjusted to allow for better system functioning. In other words: the key processes, if badly fulfilled, signal problems in the structure. By identifying where the problems are within the system they can easier be addressed by policy. For example, weakness of the function knowledge development may be caused by the lack of knowledge institutes providing appropriate courses and educating people that can work with the new technology.

\section{Methodology}

The analysis focuses on the UK, Denmark, the Netherlands and Germany because of their largest installed capacity in 2011 and potential contribution to European offshore wind industry. We analyse how the innovation systems function based on qualitative and quantitative information from several sources: scientific and industrial literature, patent analyses, European project collaboration, 4C Offshore Wind Database (version October 2010), and over 30 stakeholders' interviews (see reference list; due to confidentiality reasons not all names and functions can be published). During the interviews, experts and stakeholders from the UK, Denmark, the Netherlands and Germany were asked to express their views on the functioning of the national TISs in the European context following the diagnostic questions presented in Table 1.

We then compare the functioning of the national TISs and draw, wherever possible, general conclusions for the European
F03D patents VESTAS

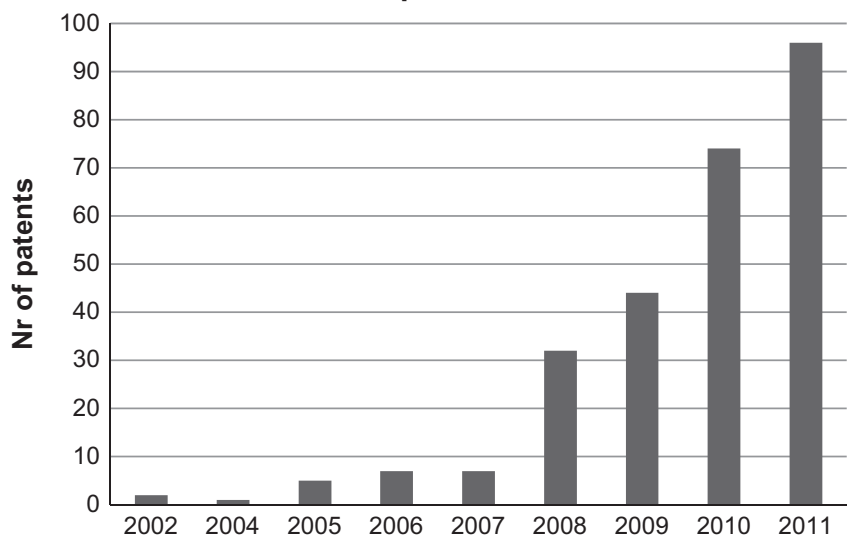

Fig. 3. Overview of wind motor patents from Vestas over time. $x$-axis: year, y-axis: no of patents.

offshore wind TIS. Based on the data we score each system functions for all four innovation systems using a 5-tier scale of absent-(1), weak-(2), moderate-(3), strong-(4), excellent-(5). This is graphically presented in Fig. 7 .

The analysis has been reviewed by 10 offshore wind experts, which provided additional information about the systems. Based on their feedback and the coupled structural-functional analysis we identify the system weaknesses that block the functioning of the four analysed TISs and have impact on the formation of the European offshore wind TIS.

\section{Analysis of innovation system functioning}

\subsection{Experimentation by entrepreneurs (F1)}

To evaluate entrepreneurial experimentation in the four analysed countries we studied the number and the type of actors involved in the offshore wind sector (incumbents ${ }^{1}$ vs. start-ups), the number and type of experimental projects of these actors, actors' involvement in national versus international projects and specialisation along the value chain.

Figs. 1 and 2 present the value chain for offshore wind in the Netherlands and the UK. The value chains for Germany and Denmark are not provided due to space limitations. Analysis of the value chains leads to the following observations:

1. Both figures show that despite the technology is still in an infant stage, a wide range of actors are present in the value chain. Interestingly, both incumbent actors from other fields and many new entrants are present. Important incumbents are the utilities (e.g., RWE (DE) and (DK)), oil and gas companies (Shell (UK, NL)), engineering firms (Siemens (DE)), offshore companies (van Oord (NL) and Mammoet (NL)) and financial firms (Typhoon Capital (NL)). Established companies that are diversifying into offshore wind bring the necessary capabilities to this emerging sector. From an innovation perspective, involvement of such (incumbent) companies effectively serves the purpose of knowledge cross-fertilisation, investor confidence and eventually the expansion of the offshore wind market.

2. The development, operation and management of wind farms are predominantly carried out by national companies and so is

\footnotetext{
${ }^{1}$ The term incumbent in innovation studies denotes an existing usually large company that has a stable position in the market.
} 


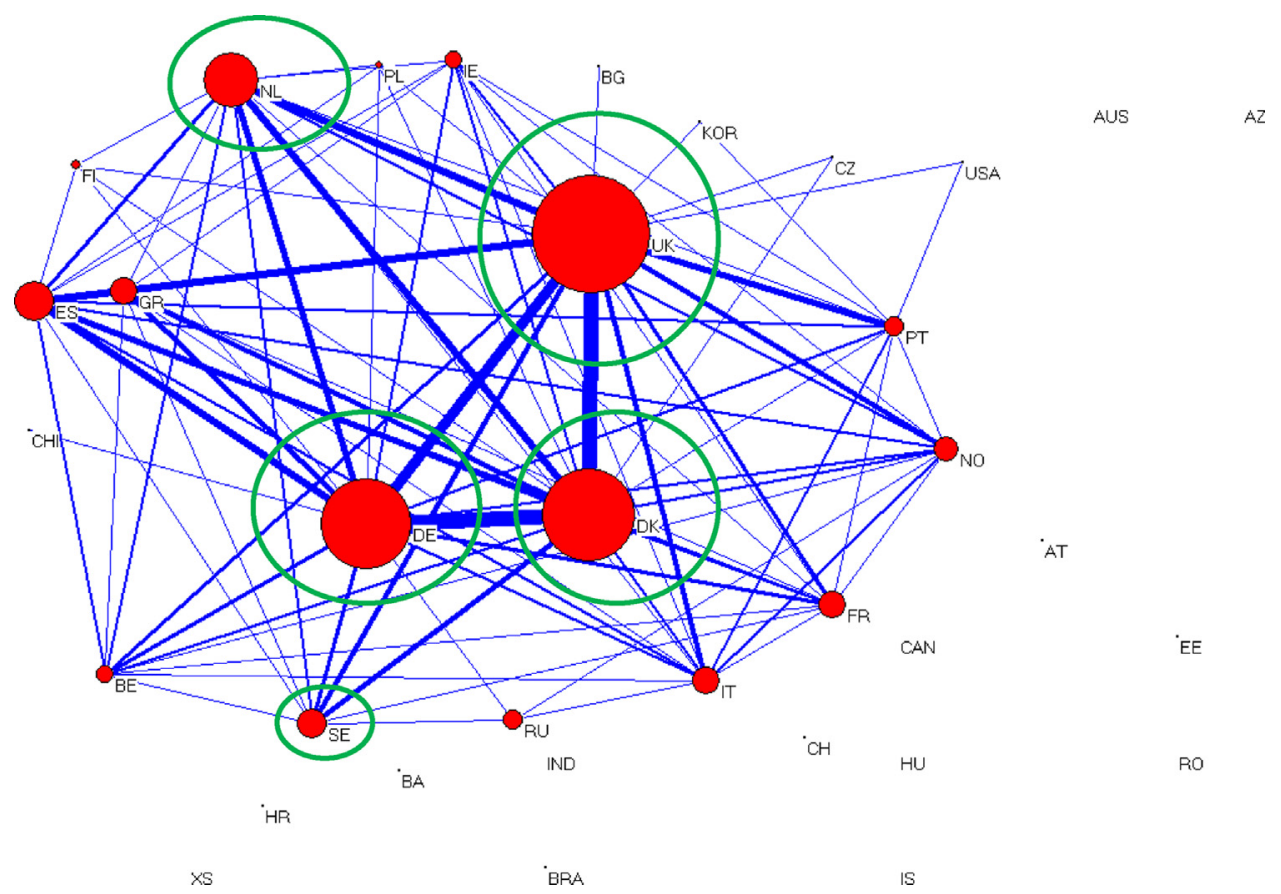

Fig. 4. European collaboration network of organizations aggregated on country level. Size adjusted for occurrence in projects, lines lower than 10 removed. The four largest collaborators: the UK, Denmark, the Netherlands and Germany circled.

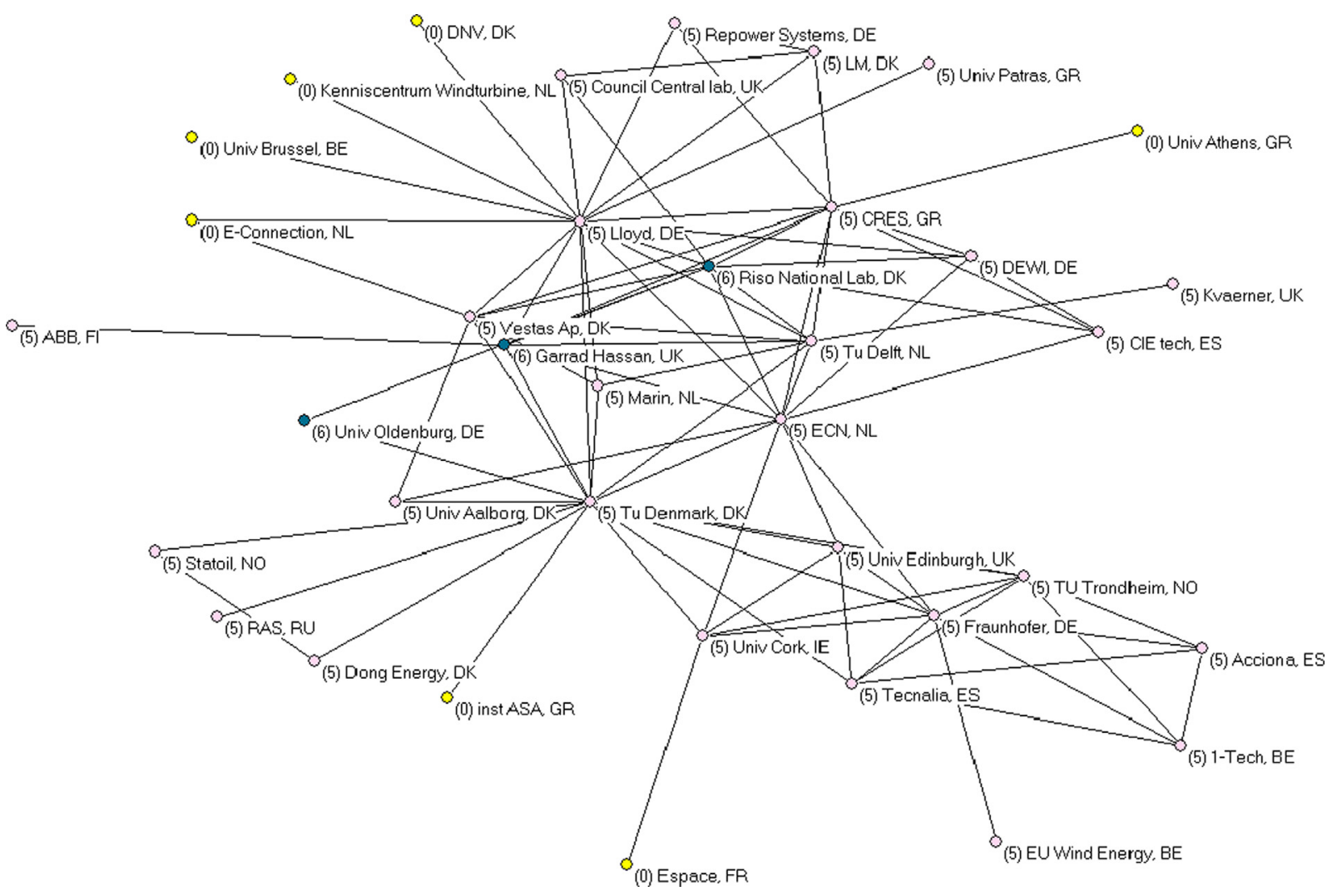

Fig. 5. The core of the CORDIS collaboration network (values lower than 3 removed, unconnected nodes are not shown).

the ownership of the projects. Large utilities such as E-on (DE), Centrica (UK), RWE (DE), Nuon (NL), Dong Energy (DK) and Eneco (NL) dominate as owners, developers and operators of the farms. This dominance is observable mostly in the UK and least in Germany where only $39 \%$ of approved offshore wind projects are owned by large utilities. The remaining shares in German wind farms are held by a great number of developers, financial investors and municipal utilities [14]. As such, Germany can be characterised by a more dispersed wind park ownership structure compared to the UK, Denmark and the Netherlands. 


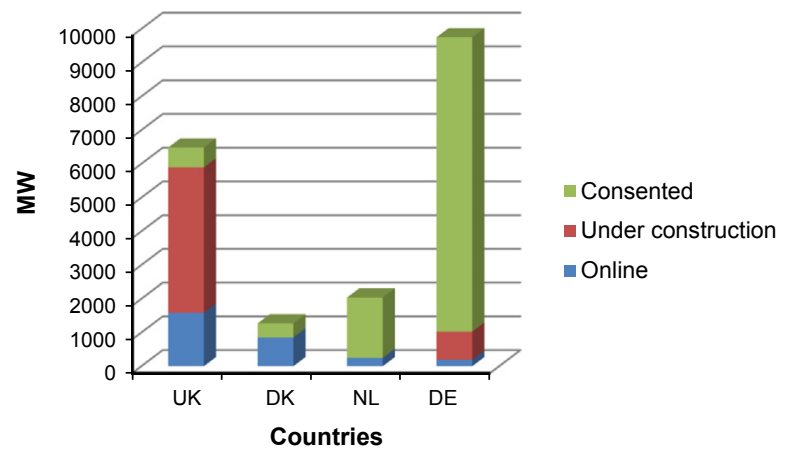

Fig. 6. Overview of MW installed (online), consented and under construction per country [3].

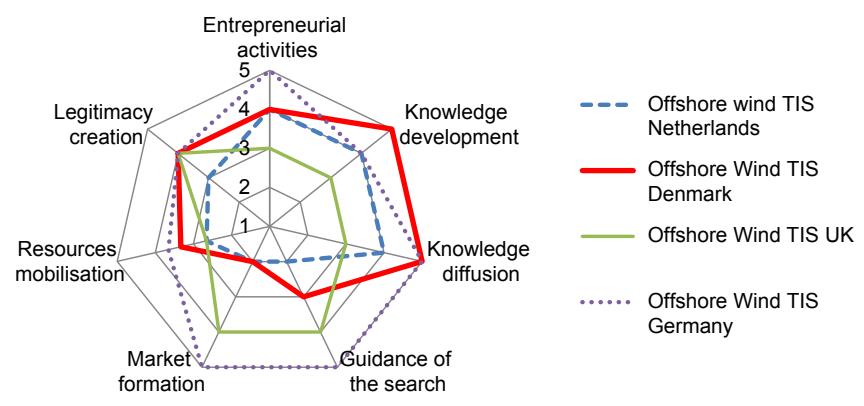

Fig. 7. Comparison of system function fulfillment in four analyzed countries.

The Dutch actors are very internationally oriented and specia-

3. lise in offshore construction [15-17]. There are more Dutch companies, especially offshore construction firms e.g. Ballast Nedam, Van Oord, Mammoet present in the foreign value chains (see Fig. 1) than the English firms (see Fig. 2). Moreover, contrary to the UK, a greater number of Dutch companies are involved in international rather than domestic projects. This implies that the Netherlands has got a very well developed construction industry (foundations, substations, and wind farm installation) for which the national market is too small. The involvement of Danish and German companies in national and international projects is relatively equally spread.

4. The UK innovation system seems most open to foreign actors and misses a strong industrial base. Fig. 2 depicts the UK offshore wind value chain and discerns UK actors (bottom) from actors from abroad (top). ${ }^{2}$ There are more non-UK than UK companies all along the UK value chain. This is not surprising. The UK, unlike Germany and Denmark, does not have a single manufacturer of the required 3-7 MW+ wind turbines. Also, the value chain for local components is small and not very complete [19], while in 2010/2011 the UK had the highest installed capacity and more offshore wind farms than any other European country. This indicates that the UK has got a developed market (demand) but a small national industry (supply) [20].

5. Two wind turbine manufacturers: Siemens (DE) and Vestas (DK) dominate in Europe, having supplied $51 \%$ and $39 \%$ respectively of installations in 2011. These two companies are followed by REpower (DE/IN) ${ }^{3}(3 \%)$, Areva (FR/DE) $<1 \%$ ) and Bard (DE)(1\%) [58]. EWEA [58] lists also a number of new entrants to the offshore wind turbine manufacturing business, such as Bard (DE) and Nordex (DE), both developing large

\footnotetext{
${ }^{2}$ Note the difference with Fig. 1 that depicts the value chain for Dutch actors, not the value chain in the Netherlands.

${ }^{3}$ With major shares of Shuzlon (India).
}

$6 \mathrm{MW}+$ wind turbines. Other newcomers from outside of the four analysed countries but important for the entire European offshore wind innovation system include: Alstom (FR), AMSC (US), Condor (UK/IT), DSME (KR), Envision (CN), Gamesa (SP), GE (US), Goldwind (CN), Northern Power Systems (US), Samsung (KR), Ming Yang (CN), Sinovel (CN), Hyundai (KR) and XEMC-Darwind (CN/NL) $[18,19]$.

6. Similarly, the substructure supply is dominated by established companies such as BiFAB (UK), Bladt (DK), Sif (NL), and Smulders (NL); with a few new entrants such as Heerema $(\mathrm{NL})$, EEW (DE), Strabag (DE) and Weserwind (DE) [3]. The presence of new entrants in the system is important so that the levels of competition and technology price stabilisation are increased. Their emergence also indicates that the value chains are quite dynamic.

7. The range of subsea high voltage cable suppliers however is limited and none of the established suppliers are located in the analysed countries: ABB ( $\mathrm{SE} / \mathrm{CH}$ ), Nexans (FR) and Prysmian (IT). NKT (DE) and General Cable (US) are the only new entrants to high voltage cable market.

8. The leading suppliers of vessels in Europe are A2Sea (DK) and Ballast Nedam (NL), Seaway Heavy Lifting (NL) and Jumbo (UK). According to EWEA [3] there are hardly any new entrants in this field and none from any of the four analysed countries. Some sources [21] expect a number of new vessels to start operating at several European offshore wind farms in 2012. However, if the new vessels do not start operating and the field develops further, the current cable and vessels suppliers may face manufacturing capacity limits [3].

9. We observe large specialisation differences along the value chain per country. Where Denmark and Germany dominate in terms of wind turbine manufacturing and related capabilities, the Dutch heavily specialise in offshore construction. The UK does not have such a strong national industry and is very dependent on foreign actors to fulfil their national ambitions. From the European offshore wind TIS perspective this specialisation along the value chain is not problematic, because the four countries seem to complement each other. Similarly, the limited number of the UK actors in the UK value chain is not problematic either as long as foreign companies do the job. However, these dependencies between nations could turn out to be problematic at national level. For example, in the UK a too strong dependence on foreign actors may result in a loss of legitimacy and political support, as domestic incentives for offshore wind primarily lead to the building up of an offshore wind industry abroad. This situation would then have serious impacts on entrepreneurial activity in all countries but especially in the Netherlands and Denmark, which in 2011 did not have a very strong offshore wind home market. German entrepreneurial activity would probably be less affected. The rather complete European offshore wind TIS may then turn out to be vulnerable due to these strong interdependencies.

In that view we evaluate the function F1 Entrepreneurial experimentation at the level of: moderate (3) in the UK, excellent (5) in Germany; and (conditionally) strong (4) in the Netherlands ${ }^{4}$ and in Denmark. Even though these are high scores, we suggest that there are more entrepreneurial experiments needed in all four countries to reduce risks and increase experience in the field.

\footnotetext{
${ }^{4}$ This score is to acknowledge the Dutch entrepreneurial activities abroad in the absence of strong domestic market. The function Market formation is assessed in the later part of this report.
} 
Table 2

Number of knowledge institutes and scientific publications on offshore wind by the UK, Danish, Dutch and German actors (1994-2010) ${ }^{\mathrm{a}}$.

\begin{tabular}{|c|c|c|c|}
\hline Country & $\begin{array}{l}\text { Total no of } \\
\text { organisations }\end{array}$ & $\begin{array}{l}\text { Total no of } \\
\text { publications }\end{array}$ & $\begin{array}{l}\text { Most important organisations } \\
\text { (incl. number of publications } \\
\text { and national percentage) }\end{array}$ \\
\hline UK & 170 & 451 & $\begin{array}{l}\text { Univ Durham }(21,5 \%) \\
\text { Univ Strathclyde Scotland }(18,4 \%) \\
\text { Univ Oxford }(16,4 \%)\end{array}$ \\
\hline Denmark & 66 & 236 & $\begin{array}{l}\text { Risø Natl Lab }(68,29 \%) \\
\text { Univ Aalborg }(33,14 \%) \\
\text { Tech Univ Denmark }(32,14 \%)\end{array}$ \\
\hline Netherlands & 43 & 140 & $\begin{array}{l}\text { Delft Univ Technol }(44,31 \%) \\
\text { Univ Utrecht }(13,9 \%) \\
\text { ECN }(13,9 \%)\end{array}$ \\
\hline Germany & 194 & 426 & $\begin{array}{l}\text { Univ Bremen }(28,7 \%) \\
\text { Leibniz Univ Hannover }(23,5 \%) \\
\text { Alfred Wegener Inst Polar \& } \\
\text { Marine Res }(22,5 \%)\end{array}$ \\
\hline
\end{tabular}

a In multi-organization papers a joint paper by two research organizations from the same country is computed once in the country profile and once for each of the author organizations.

Table 3

Most important patent classes relevant to offshore wind.

\begin{tabular}{ll}
\hline Patent code & Description \\
\hline F03D & Wind motors \\
B63B & Ships or other waterborne vessels; equipment for shipping \\
B01D & Separation \\
H02K & Dynamo electric machines \\
F03B & Machine or engines for liquids \\
E21B & Earth or rock drilling \\
E02B & Hydraulic engineering \\
F16L & Pipes; joints or fittings for pipes \\
B29C & Shaping or joining of plastics \\
\hline
\end{tabular}

\subsection{Knowledge development (F2)}

To evaluate the knowledge developed in the four analysed countries we studied the number and the type of actors involved in the knowledge development (knowledge institutes vs. industrial parties), as well as the type of knowledge developed (tacit or codified). The data is based on academic publications, patent data and interviews with experts of the field.

The main knowledge institutes that perform research on offshore wind in the four analysed countries are listed in the Table 2. It provides an overview of: (i) the total number of knowledge institutes per country, (ii) the total number of publications on offshore wind per analysed country, and (iii) the top three organisations publishing in the field per country including the number of publications per institute and the national percentage.

The total number of knowledge institutes involved in publishing in both Denmark (66) and the Netherlands (43) is much lower than in Germany (194) and the UK (170). However, the Danish and the Dutch knowledge institutes rank highest internationally in terms of the number of publications on offshore wind. In particular, the Danish Risø National Lab for Sustainable Energy and the Dutch Delft University of Technology (TU Delft) excel in their number of journal articles per institute (68 and 44 respectively).

To study the type of actors involved in the knowledge development a list of educational organisations giving courses dedicated to renewable energy, and wind in particular is shown in Table 6 (in Section 4.6). The list is long and growing in both educational categories: vocational and academic. However, only a small number of programmes specialise in the particular needs of the offshore wind sector (these are marked with $\mathrm{a}^{*}$ ).
This overview does not include organisations that offer individually arranged courses (such as PhDs).

To study the knowledge infrastructure in offshore wind we also identified patents by the keywords offshore wind. Table 3, presents an overview of the most important patent classes in offshore wind.

Most patents are classified in the area F03D (wind motors) and the large majority of these patents were filed after 2002. For illustration, Fig. 3 shows the amount of wind motor patents from Vestas over time.

In the patent class F03D, the main companies involved in manufacturing wind turbines according to the EPO patent analysis are General Electric (US) with 453 patents, Vestas (DK) with 344 patents and Siemens (DE) with 193 patents but there are also many new entrants in these areas who experiment with new designs and in doing so make the field very dynamic. The UK and Dutch organisations are not dominant players in this respect and no significant patenting activity comes from universities in any of the four countries under study.

Interviews with various offshore wind actors revealed that it is the engineering knowledge that drives the offshore wind innovation system. This knowledge is produced by companies and is often not patented nor published [16,17,19,22-25]. For example, many German firms are world leaders in dedicated R\&D, groundbreaking wind turbine and other wind technology development, and implementation of advanced offshore wind technology. Germany was the first country in the world to install an offshore 4.5 MW wind turbine in 2002: the Enercon E-112. Enercon later decided not to enter the offshore market. Another two offshore dedicated wind turbines were installed in 2004: the REpower $5 \mathrm{M}$ and Multibrid M5000. In 2005 Aerodyn Energiesysteme developed a third $5 \mathrm{MW}$ wind turbine for BARD within a record ninemonth period, of which two prototypes were installed in 2007. Also innovative foundations were developed by REpower and Weserwind (jacket), and BARD (tripile) [19]. Because of the tacit character of this knowledge, and for reasons of not losing their competitive advantage, companies do not codify nor eagerly share this knowledge [16,19,26-28], which makes its analysis very difficult.

The above data shows that there are enough competent actors that can develop both codified as well as tacit types of knowledge in all four analysed countries. From the perspective of national TISs, however, there are two points of attention. Firstly, the differences in concentration of codified knowledge production may imply for the UK and Germany the possible risk of insufficient focus and critical mass because of the distribution of resources in knowledge development. In Denmark and the Netherlands the likelihood of insufficient diversity and variety in scientific knowledge development might exist. As much as the dispersed model is useful for the training of future engineers all over the country, it may not be sufficient for the provision of advanced education that is closely linked with research [29]. A concentrated model may lead knowledge development in the field more efficiently, and make it more visible and accessible to companies who want to cooperate. A minimal amount of focus and critical mass is also necessary to contribute to and compete in the international knowledge development.

In the opinion of the interviewed stakeholders the level of knowledge developed in Europe on offshore wind is sufficient $[22,23,30-35]$. They also agree that the research focus should now shift to making the technology cost effective, particularly in relation to wind turbines and cables. The interviewees also emphasised that although companies do not eagerly share their know-how, there is good access to the European pool of knowledge on offshore wind.

Based on this analysis we evaluate the function F2-knowledge development at the level of excellent (5) in Denmark, strong (4) 
Table 4

Renewable energy targets per country.

\begin{tabular}{|c|c|c|c|c|}
\hline Country & $\begin{array}{l}2020 \text { Renewable energy } \\
\text { target (Dir. 2009/28/EC) (\%) }\end{array}$ & $\begin{array}{l}2020 \text { National renewable } \\
\text { electricity target }(\%)\end{array}$ & $\begin{array}{l}2020 \text { Projected offshore wind } \\
\text { capacity acc. to NREAP (GW) }\end{array}$ & $\begin{array}{l}2020 \text { Projected share of offshore wind in total } \\
\text { renew. Electricity (based on NREAP data) (\%) }\end{array}$ \\
\hline Netherlands & 14 & 35 (under consid.) & 5.2 & 38 \\
\hline UK & 15 & 30 & 13 & 38 \\
\hline Germany & 18 & 30 & 10 & 14 \\
\hline Denmark & 30 & & 1.3 & 26 \\
\hline EU27 & 20 & & 44 & \\
\hline
\end{tabular}

in the Netherlands (to acknowledge publications) and in Germany (to acknowledge patents) and moderate (3) in the UK.

\subsection{Knowledge diffusion (F3)}

To asses if there is enough knowledge exchanged between different actors' groups e.g. science and industry, or users and industry, and across geo borders, we looked at the number and type of networks and tried to assess the general accessibility of knowledge. We complement our findings on tacit knowledge diffusion with insights from actors' surveys.

The structural analysis of different types of networks demonstrated that knowledge networks based on collaboration on journal articles are not very extensive. Based on an analysis of the Cordis database, Fig. 4 shows that the UK, Denmark, the Netherlands and Germany are most active collaborators on research projects in Europe. All four countries have strong national research networks (such as the UK Crown Estate's Offshore Wind Accelerator [36], Renewables Innovation Network [37], Dutch Far and Large Offshore Wind (FLOW) project [38]), the German Center for Wind Energy Research Forwind [39].

Fig. 4 presents a European collaboration network of organisations aggregated on country level. Its form emphasises the centrality of the different nodes/actors in the network and shows that the UK, Denmark, the Netherlands and Germany are clear leading collaborators in the field in Europe (the four largest circles in the figure).

Fig. 5 further specifies organisations that collaborate mostly on European projects (Risø (DK), ECN (NL), TU Delft (NL), Aalborg University (DK), Vestas (DK), University Oldenburg (DE), University Edinburgh (UK)). The project collaborations show, in addition to the main organisations involved in journal publications, also a large number of companies and research organisations that do not publish but do collaborate in projects (Vestas (DK), Dong (DK), Lloyd (DE), Garrad Hassan and Partners (DE), etc.).

There are very strong lobby and industrial networks in all analysed countries [31]. A good network is seen as critical for making the new project bankable and finding a sufficient number of partners [28]. In general there is, therefore, a sense of a relatively good level of knowledge diffusion in the offshore wind sector. Parties know each other and, if necessary, through partnerships and common projects they have the possibility to gain access to each other's knowledge [24,40-45]. ${ }^{5}$ In Denmark the Offshore Centre Denmark (OCD) plays a particularly important role in the process of bringing incumbents and start-ups together at common events and pre-arranged meetings [33]. However, as mentioned before, the sharing of technological knowledge is not fully public and freely accessible because companies are wary of losing their competitive advantage. This is reflected by increasing efforts to protect innovations by patents.

We assess the function F3-knowledge diffusion in Denmark and Germany as excellent (5), strong in the Netherlands (4) and moderate in the UK (3).

\footnotetext{
${ }^{5}$ See for example [61].
}

\subsection{Guidance of the search (F4)}

To assess guidance of the search we have analysed the type of actors and their activities that influence guidance of the search; impact of informal institutions on the direction of the search (the level of governmental commitment, presence and reliability of policy goals and vision, expressed expectations); and formal institutions (presence and quality of regulatory regimes, policy instruments and permitting procedure).

Table 4 presents an overview of national renewable energy targets per country.

In the German NREAP, the German government is expecting to achieve a share of $19.6 \%$ renewable energy in total energy consumption. The overachievement of $1.6 \%$ is an expectation based on current developments but is not considered a national target. As part of the overall renewable target, Germany's federal goal [46] is to achieve $30 \%$ of its electric power generation from renewable energy sources by 2020 . According to the German NREAP renewable electricity as the percentage of total electricity production grows from $10.2 \%$ in 2005 to $38.6 \%$ in 2020 , an overachievement of $8.6 \%$.

The German government has currently the most clear and relatively consistent commitment to offshore wind among the four countries. In particular its decision to phase out nuclear power in the next 20 years ${ }^{6}$ serves the large-scale renewable market well, in which offshore wind has a significant share [47]. This commitment provides entrepreneurs with great security with respect to planning and investing [22]. It also makes German firms such as Siemens, Hochtief, OWT, PNE international market leaders $[22,23,48]$.

Denmark has a new government (started autumn 2011) [67], which wants to set the goal to $50 \%$ of energy from wind and other alternative energy sources. ${ }^{7}$ This raises hopes among the offshore wind industry for better times $[26,30,31,33]$ and high taxes on coal and gas [35].

In the UK, offshore wind is a crucial element of the government's plans to reduce the carbon intensity of the power sector, increase energy security and provide affordable energy to consumers $[27,43,44,49-51]$. In the Netherlands the current government, is not seen by stakeholders, as one that has vision or strategy, nor does it provide a stable framework for any renewable activities $[15,34,52,53]$. The guidance of the search provided by the government on the development of the domestic market for renewables is almost absent [54]. The $5.2 \mathrm{GW}$ offshore wind capacity in the Dutch National Renewable Energy Action Plan

\footnotetext{
${ }^{6}$ The plan concerns 17 of its nuclear power plants, which have met around $20 \%$ of its electrical power.

${ }^{7}$ At the moment of finalizing this paper the New Danish Energy Agreement outlined the framework for the Danish climate and energy policy until 2020 and the direction until 2050. According to this agreement $\mathrm{CO}_{2}$ emissions in 2020 will be $34 \%$ less than they were in 1990. Energy consumption will decrease by $12 \%$ in 2020 compared to 2006 . Around $35 \%$ of the country's energy will come from renewable sources and almost $50 \%$ of electricity will come from wind. It has also been decided to build a total of $3300 \mathrm{MW}$ new wind power. A part of it are two new large offshore wind farms at Kriegers Flak between Denmark and Germany (600 MW) and at Horns Reef off the west coast of Jutland (400 MW) [68].
} 
Table 5

Offshore wind policy instruments in the four analyzed countries.

\begin{tabular}{|c|c|c|c|}
\hline Country & Main policy instrument & Other financial incentives & Current support [€/MWh] [14] \\
\hline Netherlands & Feed-in premium & Fiscal investment deduction scheme & Tender outcome (if any) \\
\hline UK & $\begin{array}{l}\text { Renewable Obligation Certificate } \\
\text { (ROC) }\end{array}$ & & $\begin{array}{l}122.2 € / \mathrm{MWh} \text { certificate price for } 2 \mathrm{ROCs} \\
57.9 € / \mathrm{MWh} \text { market price for electricity incl. } \mathrm{LEC}=180.1 \\
€ / \mathrm{MWh}\end{array}$ \\
\hline Germany & Feed-in tariff & $\begin{array}{l}\text { Soft loans via KfW (state owned bank) funding } \\
\text { programmes }\end{array}$ & $\begin{array}{l}35 € / \text { MWh basic tariff } \\
130 € / \text { MWh initial tariff } \\
20 € / \text { MWh sprinter bonus (start up until } 1 \text { Jan 2016) }\end{array}$ \\
\hline Denmark & Feed-in tariff & & Tender outcome (if any) \\
\hline
\end{tabular}

(NREAP) will most likely not be realised since in 2011 the government moved its focus from relatively expensive electricity options such as offshore wind to cheaper renewable options (at least per kWh of final energy produced) such as biogas and geothermal heat. Still Dutch constructors do belong to the group of international market leaders but, contrary to the German firms, they are not backed by the national government and a strong home market. This holds considerable future risks for the Dutch, in case Germany and the UK continue to support national industry.

The national policy goals expressed in the NREAPs and driven by the common EU goals on climate change differ per country. Even though some of our interviewees doubt whether the goals will be realised. ${ }^{8}$ Still, from the guidance perspective the goals do constitute relatively stable drivers for the development of the offshore wind system in the four analysed countries and Europe as a whole. They also provide space for industrial activities, as an outcome of which, there emerge common expectations of a large market and huge potential.

What the goals do not do is provision of any guidance with regard to grid improvements $[15,30,32-35,41,42,55]$. There are different circumstances regarding grid integration in the four analysed countries. The national governments lack a consistent and coordinated (at the European level) vision on how improvements in reliability and integration of the grid should be carried out [15]. At the same time, there is a strong need to develop a pan-European grid and a crossEurope regulatory framework and trade policies [2]. Stakeholders believe that a coordinated effort in this respect will strongly drive the development of a European offshore wind. Currently the EU took some preliminary steps towards harmonised grid integration measures. The first being a memorandum of understanding that was signed by ministers from 10 EU countries to develop an offshore grid that would serve entire Northern Europe.

Overall, we conclude that the European goals provide a strong guidance for the offshore wind system development. At the national level, Germany, due to the commitment of the government and a feed-in tariff that functions well, has the strongest (5) guidance of the search (function 4). The UK is evaluated at the level of: strong (4), Denmark: moderate (3) while the Netherlands as weak (2) due to a non-existent guidance by government but a strong one by the industry.

\subsection{Market formation (F5)}

To evaluate market formation in the four analysed countries we have looked into the size of the market (installed capacity, wind parks consented and planned) and the supporting incentives.

As can be seen from Fig. 6, the UK with 1586 MW has the most grid connected wind capacity next to another $4308 \mathrm{MW}$ under construction [3]. UK is also considered the largest global market

\footnotetext{
${ }^{8}$ The interviewees do not believe in the power of non-compliance mechanisms (e.g. $[32,40])$.
}

for offshore wind [27,43,44,49]. In Germany offshore wind is developing into an extremely attractive market. Although the amount of grid connected projects is still modest (195 MW at the end of 2011), the summed capacity of consented projects is by far the greatest of all four countries analysed. Markets in both countries constitute the most profitable offshore wind development areas in the financial attractiveness ranking [56].

At the end of 2011, Denmark has the second largest grid connected offshore wind capacity (854 MW). In 2012 the $400 \mathrm{MW}$ Anholt wind farm operated by Dong is added. The next step will be the erection of six demonstration wind turbines in Fredericshavn in 2013. Compared to the UK and Germany, Denmark, however, does not have detailed long-term plans for developing Danish offshore wind capacity beyond 2013. The Dutch market is also very limited with no new farms in the pipeline. Still, three large capacity wind parks of total $1.8 \mathrm{GW}$ (Bard 1 and 2 and Q10) were already consented and their construction is planned for 2012/2013. Feed-in budget for these farms, however, were already decided upon by the government that fell in February 2010. The likelihood that other consented Dutch projects will finally be built is therefore very small.

There is a great diversity in financial incentives and policy instruments applied in various countries (see Table 5). Many interviewers consider this diversity a serious barrier [22,23,25,41,42,53].

The UK development of offshore wind is being driven by the Renewable Obligation Certificates (ROCs) regulation. Within the scheme energy companies are obliged to provide defined amounts of renewable energy. Failure incurs a fine, which is transferred as revenue to others who do meet the requirements. That means that there is no fixed price per ROC. There is, furthermore, hardly any offshore wind related manufacturing capacity in the UK and the risk for the UK is that Germany may very soon take over the leadership with regards to the size of the market.

The amount of compensation in the German feed-in tariff follows the principle of cost-covering compensation and is based on the specific electricity production costs. The plant operator receives the feed-in tariff from the grid operator. Compensation payments are distributed equally to all operators and passed on to the electricity consumers (i.e. the feed-in tariff is not paid from the state budget). The feed-in tariff is granted for 20 years and there is no annual cap.

The Dutch feed-in premium (Stimuleringsregeling Duurzame Energie+, SDE+) is the follow up regulation of the SDE. The "old" SDE for offshore wind was based on (cost-effective) ranking of competing offshore wind projects (given a limited subsidy budget for offshore wind). In the new SDE+ all renewable energy technologies together need to compete for one (limited) budget. This implies that in the new situation offshore wind has to compete with lower cost renewable energy technologies.

The most important incentive to promote offshore wind in Denmark is fixed feed-in tariff available for wind parks established via a governmental tender process, where the required tariff is a part of the bidding from the various operators. Currently there are no open tenders for offshore wind in Denmark. 
Based on these considerations we conclude that the Netherlands and Denmark, without further steps, are in a danger of losing market shares at a European level. Denmark, due to low increase in installed capacity and consented projects and no detailed longterm vision of the government; The Netherlands, due to lack of projects being in the pipeline and a lack of level playing field for offshore wind developments compared to cheaper renewable energy technologies. We evaluate the function F5 market formation: in Germany at the level of excellent (5), in the UK as strong (4), while in Denmark and in the Netherlands as weak (2).

\subsection{Resource mobilisation (F6)}

To assess the function resource mobilisation we have studied the availability of financial resources, of competencies and expertise, and of physical infrastructure.

\subsubsection{Financial resources}

Until now the availability of financial resources (capital costs) has not been very problematic. However, availability of funds (capital costs and R\&D funds) does create a significant barrier $[15,17,22,23,27,28,31,32,35,44,45]$. Due to the economic crisis in 2007 banks have decreased their loans which makes many projects financially unviable. This implies that increased numbers of banks and (international) financial organisations need to be involved in the financing of one project and a number of insurers to take the risk on board $[14,17,28,57,58]$. This has particular implications for the great number of consented and planned wind farm projects (as depicted in Fig. 6). Also the funding for nonnuclear energy R\&D proposed in the EC's 2014-2020 budget is very small and considered insufficient to achieve the EU's 20202 renewable and climate targets [58].

Germany and the UK seem to have the most certain financial situation of all four countries. The financial certainty in the UK is assured until 2014, with an average of $€ 2,3$ bn p/a (GBP 2 bn p/a). In expectation of a big market and following the ambition of the UK government to make offshore wind a part of the UK renewable energy mix-work started on identifying additional sources of capital that would allow for funding the Round 3 projects (20172022) [69]. The UK also allocated significant investments to the development of harbour infrastructure. It is a similar situation in Germany. Amongst the reforms the government confirmed that the state-backed KfW infrastructure bank will provide up to $€ 5$ bn of financing to 10 offshore wind farms, and also announced that the planned reduction in subsidies for offshore wind developers will be delayed from 2015 to 2018 [70].

In Denmark there are many pension funds who invest a great deal in wind (financial and industrial investments) [71]. They see a long-term profit from such investment because wind turbines are considered very reliable and wind is generally perceived as a safe business. By comparison, in the UK there is not enough confidence in technology (wind turbines are expensive so low-risk wind turbines are preferred) which causes many pension funds to be locked-in, financing traditional big infrastructural projects [45]. These projects are seen by the pension funds as more reliable than the renewable offshore projects, so the UK Prime Minister needs to call on investment, pension and sovereign wealth funds to back offshore wind projects [72].

In the Netherlands two large offshore wind farms are going to be constructed in 2012/2013, but the perception remains that offshore wind is a very expensive option in the near future. Despite large subsidies from the Dutch government, wind power provides merely $4 \%$ of Dutch electricity. The Dutch government is willing to invest in innovation to bring down the costs of offshore wind energy, but prices must come down considerably before large scale investments can again be supported. For the time being therefore, the government has stopped the subsidies for offshore wind power generation.

Overall, to meet their national renewable targets all four countries will face financial challenges. Increased levels of investments will be necessary for new wind farms and incentives for technology development (through R\&D and demonstration), grid improvements and integration, harbours adjustments and development of clusters around the ports.

\subsubsection{Human resources}

Currently, offshore wind is an attractive, well-paid field in Germany and Denmark $[23,26,30,33]$ but in the Netherlands young people are sceptical [15]. Also in the UK it still pays better to work for oil and gas than for the offshore wind sector [40]. This has very serious consequences for the UK who has a rapidly growing market but a quite underdeveloped domestic value chain. The UK faces a serious shortage of personnel with all types of offshore wind skills and experience: electrical, structural design, power engineers, construction and commercial managers and environmental specialists [59]. In the remaining three countries the situation is better, still various types of expertise are missing $[25,27,40-43,48,53,60,61,66]$. Denmark additionally expects a generation gap when current professionals will have to retire, and there will be either too few new experts, or they will have little practical experience $[33,53]$ Shortage of skilled labour makes companies educate personnel internally $[16,17,23,24]$ or attract them from other companies. This serves for a relatively high level of mobility of offshore wind experts in Europe [22,35]. All four countries make attempts to address this problem by designing an increasing number of offshore wind educational programmes and courses (see Table 6). Denmark and the Netherlands are frontrunners in academic and polytechnic training. programme.

There is also intensifying European collaboration on education, which is a sign of the need to harmonise and coordinate the system at the European level. The European Academy of Wind Energy (EAWE) provides many courses on offshore wind. EAWE is a registered body of research institutes and universities in Europe (the UK, Denmark, the Netherlands and Germany included) working on wind energy research and development [73]. The training and educational programmes are thus quite recent and sill insufficient to the needs. Europe-wide cuts on funding for the higher education sector pose additional threats [58].

\subsubsection{Physical resources}

With respect to physical resources, three issues repeatedly dominate the discussion in all four analysed countries: the reliability and cost of technology, availability of cables, deficiency of the grid infrastructure and problems related to grid connection [63].

Especially, grid stability and capacity is an enormous issue in all of Europe [15,22,23,26-28,30,32-35,41,42,53,55,80]. The European grid requires modification and renovation to be able to accept larger amounts of renewable energy [58]. There are also difficulties with securing grid access with financial implications relating to where the connection takes place. Trends suggest, for example, that linking wind parks into hubs before connecting them to the grid is less expensive than connecting them individually but no common grid strategy is as yet developed [64]. All four countries have works underway to improve their part of the grid. However, the indecisiveness of many national governments with regards to the future energy mix, and in particular the renewable share, makes any common action rather difficult $[55,74,75]$.

Regarding cables' availability, there are issues with fluctuating copper prices and a general lack of, especially the high-voltage export cables $[23,41,76,77]$. Cable companies complain that cable orders for offshore wind farms come too late for them to timely 
Table 6

Organisations offering renewable energy courses relevant for offshore wind field. ${ }^{a}$

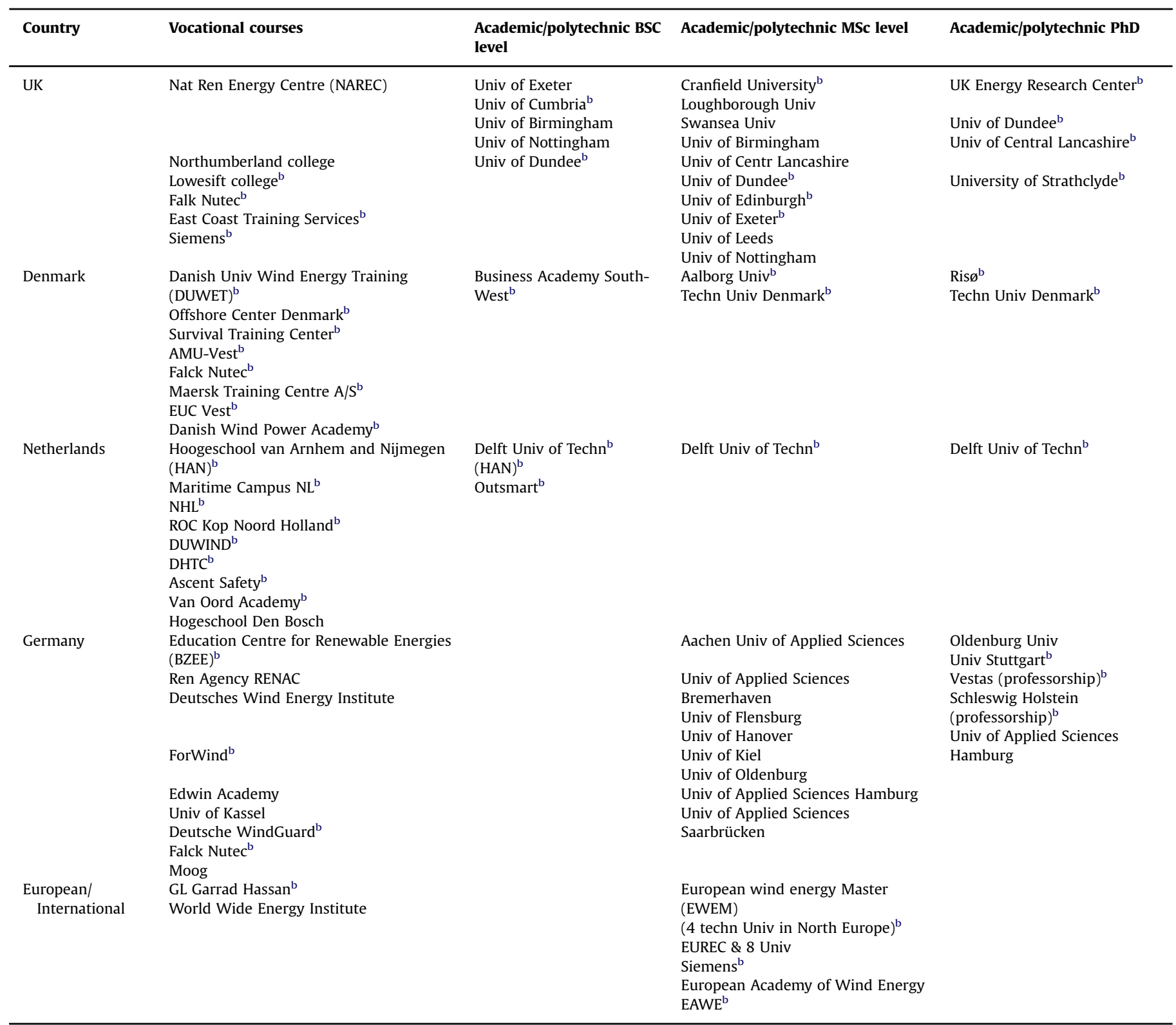

${ }^{\text {a }}$ Based on Ref. [62] and websites of the organizations accessed on 2 Feb 2012

${ }^{\mathrm{b}}$ Denotes that the organisation gives a dedicated offshore wind module, specialisation or introduction within their educational programmes portfolio.

and economically deliver the order. This often makes the costs of wind farm project suddenly higher than anticipated [40].

Scarcity of vessels is not found to be very problematic at the moment of analysis. However, many interviewees emphasised that innovations are needed to adjust the vessels for operation in deep waters $(>50 \mathrm{~m}$ ), and for performance of a variety of tasks $[16,17,24,27,40,41]$. Presently around 50-60 different types of dedicated vessels are needed for one farm installation. In the future, if the offshore wind system develops, the scarcity of specialised, deep water vessels may therefore become a serious constraint [78].

Finally, all countries also have a good harbour capacity, particularly the Netherlands, the UK and Denmark serving the oil and gas industry. However, almost all harbours need to be adjusted to be able to serve the offshore wind operations [3]. Some, such as Rotterdam, face societal opposition because their adjustment to meet offshore wind standards would imply territorial extension into the city and intensification of activities, entailing increased noise, transport and pollution.

We assess function F6: resource mobilisation in the following way: financial resources in the Netherlands as weak (2), in Denmark moderate (3), in Germany and the UK strong (4). We rate human resources as strong (4) in Germany and Denmark, moderate (3) in the Netherlands, weak (2) in the UK. Physical resources: weak (2) in the UK and moderate (3) in the three remaining countries.

\subsection{Legitimacy creation (F7)}

To evaluate if there is enough creation of legitimacy we have analysed the level of resistance to technology, the perceived level of competition between technologies and the extent to which the formal and informal institutions increase legitimacy.

In terms of legitimacy in specific countries, much depends on the extent to which offshore wind is needed to meet the national 
renewables target. A second factor is the extent to which the national governments see offshore wind as a means to develop national industry and create jobs. In Germany and the UK, for example, the national visions, the support programmes and measures are the most developed. They are therefore considered by the interviewees as contributing most to increasing the legitimacy of offshore wind. Also Denmark (with the new greener government) sees offshore wind as a major future contributor to the national energy production $[26,30,31,33,35]$. In the Netherlands: the lack of vision, absence of any consistent programme and poor subsidy scheme, are the factors most limiting the legitimacy of this renewable energy technology [15,34].

The informal institutions, especially the expectations regarding the robustness and availability of technology and markets, are in our view very optimistic. However, the technology will not have proven itself for another several years. If it does not, the failed expectations may create tensions. Risk perception is another issue that is of great importance for this very capital intensive sector. The increased levels of risk are due to lack of confidence in technology [42]. Banks are often risk-avoiding and therefore unwilling to finance wind farms comprising new wind technology without track record $[17,25,27,53]$. At the time of the financial crisis many banks lowered their offshore wind energy project funds making it difficult to install a wind farm without involvement of more financial organisations [28]. Furthermore, uncertainties about the grid connection and overall lack of alignment of the vision on grid improvements, additionally hinder the legitimacy creation.

None of the analysed countries reveal any significant societal opposition to offshore wind farms as long as the wind turbines are not visible from the shore and there is no huge impact of construction on the local public $[16,17,22,24-26,30,31,33,34,40,48,53,65]$. We therefore rate function F7: creation of legitimacy at the level of weak (2) in the Netherlands and strong (4) in the UK, Germany and Denmark.

\subsection{Comparison of overall system functioning}

Comparison of the functional pattern of the four offshore wind innovation systems (Fig. 7) reveals that entrepreneurial activities are relatively strong in all four countries but are strongest in Germany. In Denmark knowledge creation excels while the UK scores relatively low. Knowledge diffusion is strongest in Germany and Denmark but low in the UK. Market formation processes are by far the best in Germany, good in the UK but very weak, almost non-existent in the Netherlands and Denmark. Resources mobilisation is equally weak in all four analysed TISs, while legitimacy creation scores on average slightly higher. Still it is equally low in all four countries.

Based on this analysis we can conclude that there is not only a strong need for, but in fact already an emergence of, a European offshore wind innovation system. Fig. 7 shows the extent to which the national TISs contribute to the European innovation system. A strong indicator of European system emergence is the visible complementary specialisation of the four countries in entrepreneurial experimentation and knowledge creation. While in the national context this specialisation may have rather negative implications such as loss of national legitimacy or leakage of financial resources, from the European perspective it works to the advantage of the sector.

\section{Conclusions and challenges for the European offshore wind TIS}

Offshore wind technology holds the potential for tackling major energy issues, climate change problems and creating jobs and economic growth. However, to develop further, three innovation system's processes require particular policy attention. These processes include: resource mobilisation (as described by function F6), market formation (function F5) and legitimacy creation (function F7). The processes are hindered by either the absence or by the malfunctioning of the specific structural elements of the innovation systems. Based on our analysis we suggest that to support the formation of the European offshore wind innovation system, the following issues require prompt policy attention:

First, is has become evident that national policies, instruments and regulatory frameworks differ strongly and are not aligned. Similarly, a uniform European grid strategy and electricity trade code is still lacking. A more European perspective on this industry, instead of individual national perspectives, would be beneficial for the offshore wind sector.

Second, this emerging sector is experiencing shortages of skilled labour. This is most likely one of the most serious problems in the near future as the sector expands. The development of adequate training programmes proves to be a time consuming process but needs to commence now.

Third, the costs need to be reduced and the reliability of offshore wind farms must increase. This will logically be the result of increased market size and cumulative learning experiences. However, due to the high capital costs and reduced liquidity of financial markets there is a clear trend towards avoiding experimentation with new designs and new construction methods as it may increase risks. We observe that this technological field is too immature to avoid investing in innovative procedures and technologies.

Fourthly, the grid infrastructure requires renewal with respect to better access and expansion to accommodate growing amount of renewable energy. Because of the lack of common European vision and coherent electricity market, grid issue is not only a technical obstacle but also an institutional barrier requiring a stable regulatory framework at the European level.

We recommend that an orchestrated policy effort is applied, built around the above challenges, in order to strengthen the development and functioning of the European offshore wind innovation system. This would be essential for the diffusion of offshore wind technology in Europe and, in the long run to the achievement of the European 2050 vision of moving to a competitive low carbon economy [1,81].

\section{Acknowledgements}

This paper is based on a report prepared for the JRC's Institute for Energy and Transport [79]. The authors acknowledge valuable and constructive contributions of: Sylvian Watt-Jones (Utrecht University); Eize de Vries (Rotation Consultancy, consultant for Windpower Monthly), Ernst van Zuijlen (Flow, NWEA); Theo de Lange (Van Oord); Jan van der Tempel (TU Delft), and Remco Borsma (NUON), Staffan Jacobsson (Gothenburg University Sweden), Morten Holmager (Offshore Center Denmark), Athanasia Arapogianni (EWEA, Brussels), Michiel Heemskerk (Rabobank), Kiti Suomalainen (JRC), Roberto Lacal-Arántegui (JRC), Evangelos Tzimas (JRC), Ad van Wijk (TU Delft).

\section{References}

[1] EC. A roadmap for moving to a competitive low carbon economy in 2050; 2011.

[2] EC. Energy 2020. A strategy for competitive, sustainable and secure energy; 2011.

[3] EWEA. Wind in our sails-the coming of Europe's offshore wind energy industry. Brussels: The European Wind Energy Association; 2011p. 11. 
[4] EEA. European Environmental Agency Technical report 6/2009: Europe's onshore and offshore wind energy potential. 2009 An assessment of environmental and economic constraints.

[5] EC. Innovation Union 〈http://ec.europa.eu/research/innovation-union/index_en. cfm accessed 04/2012 $\rangle$.

[6] Negro SO, Alkemade F, Hekkert MP. Why does renewable energy diffuse so slowly? A review of innovation system problems Renewable and Sustainable Energy Reviews 2012;16:3836-46.

[7] Wieczorek AJ, Hekkert MP. Systemic instruments for systemic innovation problems: a framework for policy makers and innovation scholars. Science and Public Policy 2012;39:74-87.

[8] Hekkert MP, Suurs R, Negro SO, Kuhlmann S, Smits REHM. Functions of innovation systems: a new approach for analyzing technological change. Technological Forecasting and Social Change 2007;74:413-32.

[9] Bergek A, Jacobsson S, Carlsson B, Lindmark S, Rickne A. Analyzing the functional dynamics of technological innovation systems: a scheme of analysis. Research Policy 2008;37:407-29.

[10] Markard J, Truffer B. Technological innovation systems and the multi-level perspective: towards an integrated framework. Research Policy 2008;37: 596-615.

[11] Crawford S, Ostrom E. A grammar of institutions. American Political Science Review 1995:98:582-600.

[12] Lipsey R, Carlaw KI, Bekar CT. Economic transformations. General purpose technologies and long term economic growth. Oxford: OUP; 2005.

[13] Edquist C, editor. Systems of innovation: technologies, institutions and organizations. London: Pinter; 1997.

[14] KPMG. Offshore wind in Europe. 20102010 market report.

[15] Ecofys. Wind Energy, The Netherlands. Pers comm with a repres. In: Proceedings of EWEA conference, 29/11-1/12/2011. Amsterdam, The Netherlands.

[16] Volker Staal en Funderingen (VSF). The Netherlands. Pers comm with 2 repres. In: Proceedings of EWEA conference, 29/11-1/12/2011. Amsterdam, The Netherlands.

[17] Van Oord Offshore Wind Projects BV. The Netherlands. Pers comm with a repres. In: Proceedings of EWEA conference, 29/11-1/12/2011. Amsterdam, The Netherlands.

[18] Van Zuilen E. FLOW. Pers comm, Amsterdam; April 2012.

[19] De Vries E. Wind power monthly. Pers comm, Rotation company. Amsterdam; April 2012

[20] Westwood D. Offshore wind: building an industry. Analysis and scenarios for industrial development.

[21] Bloomberg New Energy Finance. Offshore wind market outlook, 13.01.12 〈http://www.docin.com/p-194017138.html〉 [accessed 04.12].

[22] RWE, Germany. Pers comm with a repres. In: Proceedings of EWEA conference, 29/11-1/12/2011. Amsterdam, NL.

[23] Siemens Wind Power A/S, Denmark and Germany. Pers comm with 2 repres. In: Proceedings of EWEA conference, 29/11-1/12/2011. Amsterdam, NL.

[24] MPI Workboats, UK. Pers comm with a repres. In: Proceedings of EWEA conference, 29/11-1/12/2011. Amsterdam, NL.

[25] Kema, Arnhem, The Netherlands. Pers comm with a repres. In: Proceedings of EWEA conference, 29/11-1/12/2011. Amsterdam, NL.

[26] DONG Energy, Denmark. Pers comm with a repres. In: Proceedings of EWEA conference, 29/11-1/12/2011. Amsterdam, NL.

[27] DONG Renewable Energy, UK. Pers comm with a repres. In: Proceedings of EWEA conference, 29/11-1/12/2011. Amsterdam, NL.

[28] Rabobank, The Netherlands. Pers comm with a repres. In: Proceedings of EWEA conference, 29/11-1/12/2011. Amsterdam, NL

[29] Jacobsson S. Goteborg University. Pers comm. Amsterdam; March 2012.

[30] Seas NVE, Denmark. Pers comm with 2 repres. In: Proceedings of EWEA conference, 29/11-1/12/2011. Amsterdam, NL.

[31] Jutlandia, Denmark. Pers comm with a repres. In: Proceedings of EWEA conference, 29/11-1/12/2011. Amsterdam, NL.

[32] Esbjerg Business Development Center, Denmark. Pers comm with 2 repres. In: Proceedings of EWEA conference, 29/11-1/12/2011. Amsterdam, NL.

[33] Offshore Center Denmark (OCD). Pers comm with a repres. In: Proceedings of EWEA conference, 29/11-1/12/2011. Amsterdam, NL.

[34] Netherlands Wind Energy Association (NWEA). Pers comm with 2 repres. In: Proceedings of EWEA conference, 29/11-1/12/2011. Amsterdam, NL.

[35] A2Sea, Denmark. Pers comm with a repres. In: Proceedings of EWEA conference, 29/11-1/12/2011. Amsterdam, NL.

[36] 〈http://www.carbontrust.com/our-clients/o/offshore-wind-accelerator $\rangle$.

[37] 〈http://www.renewables-innovation.co.uk〉 [accessed 02.12].

[38] 〈http://flow-offshore.nl/images/2011-08/flow_samenvatting.pdf [accessed 02.12].

[39] 〈http://www.forwind.de [accessed 02.12].

[40] JDR Cable Systems LTD, UK. Pers comm with a repres. In: Proceedings of EWEA conference, 29/11-1/12/2011. Amsterdam, NL.

[41] RenewableUK, UK. Pers comm with a repres. In: Proceedings of EWEA conference, 29/11-1/12/2011. Amsterdam, NL.

[42] 4C Offshore, UK. Pers comm with a repres. In: Proceedings of EWEA conference, 29/11-1/12/2011. Amsterdam, NL.
[43] KBR, UK. Pers comm with 2 repres. In: Proceedings of EWEA conference, 29/ 11-1/12/2011. Amsterdam, NL.

[44] PMSS, UK. Pers comm with a repres. In: Proceedings of EWEA conference, 29/ 11-1/12/2011. Amsterdam, NL

[45] Typhoon Offshore, UK. Pers comm with a repres. In: Proceedings of EWEA conference, 29/11-1/12/2011. Amsterdam, NL.

[46] EEG. German Renewable Energy Act; 2009.

[47] Schultz S. Will nuke phase-out make offshore farms attractive? Spiegel Online; 23/03/2011.

[48] Germanischer Lloyd Renewable Certification (GL), Germany. Pers comm with a repres. In: Proceedings of EWEA conference, 29/11-1/12/2011. Amsterdam, NL.

[49] BWEA. UK offshore wind: charting the right course. Scenarios for offshore capital costs for the next five years; 2011.

[50] The Crown Estate. Offshore wind report 2011. 2011.

[51] Department of Energy and Climate Change: the UK renewable energy roadmap; 2011.

[52] Rabobank. An outlook for renewable energy in the Netherlands. Rabobank Industry note \#320; June 2012.

[53] Alstom, The Netherlands. Pers comm with a repres. In: Proceedings of EWEA conference, 29/11-1/12/2011. Amsterdam, NL.

[54] Verdonk M, Wetzels W. Referentieraming energie en emissies: actualisatie 2012 energie en emissies in de jaren 2012, 2020 en2030, ECN; 2012.

[55] EWEA. Pers comm with 2 repres. In: Proceedings of EWEA conference, 29/111/12/2011. Amsterdam, NL.

[56] Prässler T, Schaechtele J. Comparison of the financial attractiveness among prospective offshore wind parks in selected European countries. Energy Policy 2012;45:86-101.

[57] Guillet J. Banking offshore wind. Chapter 03 in pfi intelligence briefing; 2011 〈http://www.green-giraffe.eu/uploads/0911\%20PFI\%20Financing\%200ffshore\% 20Wind\%20\%20\%28JG\%29.pdf .

[58] EWEA. Bridging the gaps. Brussels: Wind directions; 2012

[59] RenewableUK. Working for a Green Britain. Future employment and skills in the UK wind and marine industries. ; 2011.

[60] INTPOW. Offshore wind germany market study 2011. Norwegian Renewable Energy Partners; 2011

[61] 〈http://www.offshorewind.biz/2012/08/07/shared-knowledge-could-enhan ce-offshore-wind-industry-for-germany-uk/> [accessed 08.12].

[62] Wind Power Monthly 2012.

[63] Edwards I. Overcoming challenges for the offshore wind industry and learning from the oil and gas industry. Natural Power 2011.

[64] OffshoreGrid. Offshore electricity grid infrastructure in Europe. A technoeconomic assessment; 2011.

[65] Jones CR, Eiser JR. Understanding 'local' opposition to wind development in the UK: how big is a backyard? Energy Policy 2010;38:3106-17.

[66] Jacobsson S, Karltorp K. Formation of competencies to realize the potential of offshore wind power in the European Union. Energy Policy 2012;44:374-84.

[67] 〈http://www.denmark.dk/en/menu/About-Denmark/Government-Politics/〉 [accessed 04.12].

[68] 〈http://www.offshorewind.biz/2012/04/16/new-danish-energy-agreementmakes-denmark-safe-investment/ $\rangle$ [accessed 04.12].

[69]〈http://www.thecrownestate.co.uk/media/229356/owdf_04_01_finance_ group_paper.pdf $\rangle$ [accessed 04.12]

[70] 〈http://www.businessgreen.com/bg/news/2100019/germany-enjoys-surge-off shore-wind-investment $\rangle$ [accessed 04.12].

[71] 〈http://www.ft.com/intl/cms/s/0/7740d04c-5c9c-11e0-ab7c-00144feab49a. html\#axzz282JQwcp6 $\rangle$, [accessed 04.12].

[72] 〈http://www.energyefficiencynews.com/articles/i/4677/ $\rangle$, [accessed 04.12]

[73] 〈www.eawe.eu [accessed 02.12].

[74] 〈http://www.offshorewind.biz/2012/10/12/uk-european-offshore-wind-deve lopment-shaken-by-political-uncertainty/ $\rangle$ [accessed 05.12].

[75] 〈http://www.smartenergyjournal.com/2012/09/29/political-uncertainty-dama ges-investors-confidence-in-green-energy/ $\rangle$ [accessed 09.12]

[76] 〈http://www.supplymanagement.com/2012/wind-farm-cables-face-global-de ficit $/\rangle$ [accessed 09.12].

[77] 〈http://www.powerengineeringint.com/articles/print/volume-20/issue-5/fea tures/going-the-distance.html $>$ [accessed 09.12].

[78] 〈http://www.offshore-technology.com/features/featureoperation-maintenan ce-offshore-wind-oil-gas-hydrocarbons-installed-capacity-wind-farm-speciali sed-resources-ship-boat-vessel-installation/> [accessed 09.12].

[79] Wieczorek AJ, Negro SO, Harmsen R, Heimeriks GJ, Hekkert MP. A systemic assessment of the European offshore wind innovation system based on insights from the UK, Denmark, the Netherlands and Germany, JRC, Petten; 2012.

[80] O'Keeffe A, Haggett C. An investigation into the potential barriers facing the development of offshorewind energy in Scotland: case study-firth of forth offshore wind farm. Renewable and Sustainable Energy Reviews 2012;16 (6):3711-21.

[81] Jacobsson S, Karltorp K. Mechanisms blocking the dynamics of the European offshore wind energy innovationsystem-challenges for policyintervention. Work in progress, 2013 